\title{
Nutrient Analysis, Decomposition, and Nitrogen Mineralization of Various Organic Amendments Used for Pechay Production
}

\author{
Clea Anne E. Vallejera ${ }^{1}$, Anabella B. Tulin ${ }^{1,2}$, Victor B. Asio ${ }^{1}$ and \\ Chris G. Dorahy
}

${ }^{1}$ Department of Agronomy and Soil Science, VSU, Baybay City, Leyte, ${ }^{2}$ Soils and Plant Environment Laboratory, PhilRootcrops, VSU, Baybay City, Leyte and ${ }^{3}$ Ableblue Ltd. Pty., Narren, Victoria, Australia

\begin{abstract}
Farmers are increasingly using alternative fertilizer inputs such as manures and composts due to the high cost of inorganic fertilizers. However, different organic amendments have varied characteristics and thus also their effects on soil properties and the growth and yield of crops. The study was conducted to determine the characteristics and nutrient content of organic amendments, evaluate the decomposition rate and nitrogen mineralization rate of the various organic amendments, and examine the effects of different organic amendments on pechay. Four organic amendments used include swine manure, chicken dung, mudpress, and vermicast. These were analyzed for total elemental analysis, microbial decomposition, and nitrogen mineralization rate. A pot experiment was carried out to test the effects of these amendments on the growth and yield of pechay. Results showed that organic amended soil significantly increased the rates of microbial decomposition and nitrogen mineralization, organic material content, and the growth and yield of pechay. In terms of total elemental analysis, chicken dung had the highest content of essential nutrients such as $\mathrm{P}, \mathrm{K}, \mathrm{Ca}$, and $\mathrm{Cl}$ as compared to mudpress, vermicast, swine manure, hence, has good potential as source of organic fertilizer for vegetable production. High amounts of heavy metals such as lead, strontium, nickel, copper, and zinc were detected in the swine manure.
\end{abstract}

Key words: amendments, total elemental analysis, nitrogen mineralization, pechay.

Correspondence : A.B. Tulin Address: Soils and Plant Environment Laboratory, PhilRootcrops, VSU, Baybay City, Leyte E-mail: belle2460@yahoo.com Tel: 053-335-2616

DOI: $10.32945 /$ atr3617.2014 


\section{INTRODUCTION}

Vegetables are important in supplying the food and nutritional needs of the people. They are capable of producing more than five times the quantities of food per unit area when compared to cereal crops. With such high yield potential, vegetable production may help solve the food problems of the nation's deficiency in supplies of food. Thus, it is necessary to intensify the production of vegetable crops to meet the nutrient requirements of the fast growing country's population.

However, a number of barriers exist to achieve high production of vegetables such as diminishing arable lands, declining soil fertility, high fertilizer costs, lack of capital for purchasing fertilizer inputs and lack of grower expertise in soil management and crop agronomy (Dorahy et al., 2010 and Tulin et al., 2010). To address these issues, one strategy to ameliorate soil fertility decline and to improve crop yields is through fertilizer application. Unfortunately, the prices of fertilizers are getting higher making them unaffordable to vegetable growers. There is a need for alternative fertilizers which are cheap and locally available like compost and animal manure. Application of organic materials increases the organic matter content of the soil and influences the biophysico-chemical properties of the soil as well as the release of nutrients. They serve as a slow-reservoir for plant macronutrients (especially nitrogen) and also aids in plant micronutrient nutrition (Mitchell et al., 2000). However, different organic amendments vary in their characteristics and nutrient contents which in turn greatly determines how they affect the soil and the crop planted. Thus, there is a need to characterize these organic materials in order to determine how they can best increase crop production.

The study aimed to evaluate the characteristics and nutrient contents of various organic amendments used for vegetable production in Leyte, evaluate their decomposition and nitrogen mineralization rates, and examine the effects of the organic amendments on pechay growth and development.

\section{MATERIALS AND METHODS}

\section{Collection of Organic Amendments}

Commonly used organic amendments by vegetable farmers in Leyte were collected from various sources. Shortly after collection, the materials were air-dried, pounded using a wooden mallet, and sieved using $2 \mathrm{~mm}$ 
mesh sieve. Prior to analysis, a subsample of each of the sieved organic material was ground for total elemental analysis. Another subsample of sieved organic material was taken for organic matter content alaysis, nitrogen mineralization, and microbial decomposition determination for potexperiment study.

\section{Collection and Preparation of Soil}

Bulk surface soil sample $(0-20 \mathrm{~cm}$ depth) was collected from Cabintan, Ormoc City. Any obvious concretions including rock fragments and organic debris were removed from the soil samples before these were air-dried. The samples were then homogenized and sieved in a $2 \mathrm{~mm}$ wire mesh screen and were set aside for the different experiments in the study. The soil was weighed according to the specified amounts needed in each parameter.

\section{Nutrient Content Analysis}

\section{Total Elemental Analysis}

This was analyzed by the Philippine Nuclear Research Institute (PNRI) in Quezon City. The procedure was as follows: Samples were prepared as a 31-mm pellet, placed in a sample cup, and analyzed qualitatively by X-ray Fluorescence (XRF) Spectrometry using the Analytical Epsilon 5 XRF System. This method was used to identify and estimate the elemental contents of the samples. A blank determination was also done using an empty but similarly configured sample cup.

\section{Microbial Decomposition Rate}

This was carried out following the procedure of Anderson (1982) by estimating the amounts of carbon dioxide evolution from soil incorporated with organic materials. The experiment used $100 \mathrm{~g}$ soil placed in 1 liter jar and incubated at room temperature for a month and data were collected on a weekly basis. The treatments were as follows:

$$
\begin{array}{lc}
\mathrm{T}_{0} \text { - soil alone (control) } & \mathrm{T}_{3} \text {-soil + mudpress } \\
\mathrm{T}_{1} \text { - soil + swine manure } & \mathrm{T}_{4}-\text { soil + vermicast } \\
\mathrm{T}_{2} \text { - soil + chicken dung } &
\end{array}
$$


Fifty (50) g of each organic amendment was weighed and incorporated into the soil and mixed well. Each treatment was replicated three times. A $50 \mathrm{~mL}$ beaker containing $20 \mathrm{~mL}$ of $1 \mathrm{~N} \mathrm{NaOH}$ was placed on the surface of the organic amended soil mixture and was sealed tightly. After completing the incubation period every week, the beaker containing the alkali was added with $1 \mathrm{~mL}$ of $50 \% \mathrm{BaCl}_{2}$ and 2-3 drops of phenolphthalein indicator and was titrated slowly with $1 \mathrm{~N} \mathrm{HCl}$ until the pink color disappeared. The amount of acid used to neutralize the base was recorded. Milligrams of $\mathrm{CO}_{2}$ evolved were calculated using the formula:

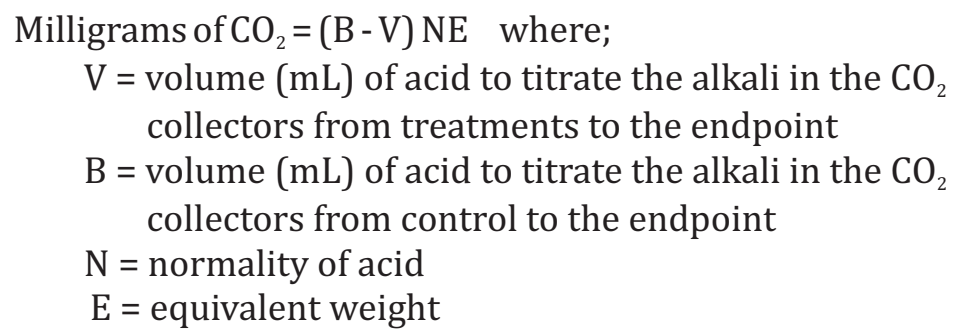

To express the data in terms of $\mathrm{CO}_{2} \mathrm{E}=22$.

\section{Nitrogen Mineralization Study}

Five hundred (500) g of soil (oven-dry weight based) was placed in each polyethylene bag $(5 \times 5 \times 10 \mathrm{~cm})$ placed at a distance of $25 \mathrm{~cm} \times 25 \mathrm{~cm}$ apart under an improvised protective structure having a plastic roofing.

Incorporation of organic materials was done one day after placing the polybags in the selected area. The organic materials were placed separately in each bag and mixed well with the soil so as to make them more accessible to microbial attack. The amounts of each organic material was equivalent to $120 \mathrm{~kg} \mathrm{~N} / \mathrm{ha}$ applications based on the recommended rate for pechay. The computation of the added organic materials was based on prior analysis of total $\mathrm{N}$ content of each material multiplied by the amount of mineralizable N/yr (2.5\%) (Blackmer, 2000; Troeh and Thompson, 1993). Addition of water every after one day was based on $60 \%$ field capacity (Schlichting et. al., 1995).

The treatments were as follows:

$$
\begin{aligned}
& \mathrm{T}_{0}-\text { control (no application) } \\
& \mathrm{T}_{1}-\text { swine manure }(2.81 \% \mathrm{~N})-67 \mathrm{~g} / 500 \mathrm{~g} \text { soil } \\
& \mathrm{T}_{2}-\text { chicken dung }(4 \% \mathrm{~N})-47 \mathrm{~g} / 500 \mathrm{~g} \text { soil } \\
& \mathrm{T}_{3}-\text { mudpress }(0.69 \% \mathrm{~N})-234 \mathrm{~g} / 500 \mathrm{~g} \text { soil } \\
& \mathrm{T}_{4}-\operatorname{vermicast}(1.13 \% \mathrm{~N})-156 \mathrm{~g} / 500 \mathrm{~g} \text { soil }
\end{aligned}
$$


Soil sampling was done under three mineralization periods: a) prior to organic amendments, b) weekly determination for the first four weeks, and c) biweekly determination for the second four weeks.

Soil sample from the previously prepared soil was collected prior to the incorporation of organic materials for initial analysis. Weekly determination of mineralized nitrogen was done for the first four weeks and biweekly for the second four weeks. Fifty (50) g of organic amended soil mixture were collected in each treatment at each specified mineralization periods.

\section{Inorganic Nitrogen}

The amount of mineral nitrogen was analyzed using the procedure described by Stanford and Smith (1972) at these mineralization periods:

1)Prior to organic material incorporation

2)Weekly determination for the first four weeks

3)Biweekly determination for the second four weeks

Organic amended soil mixture samples were collected from each treatment and were extracted with $1 \mathrm{~N} \mathrm{KCl}$ and analyzed for mineralizable $\mathrm{NO}_{3}{ }^{-}$and $\mathrm{NH}_{4}{ }^{+}$Following the procedure of Bremmer (1965).

Percent $\mathrm{N}$ mineralized was computed using the formula:

$$
\% \mathrm{~N} \text { mineralized }=\frac{\text { Total inorganic } \mathrm{N} \text { mineralized }(\mathrm{ppm})}{\% \text { Total } \mathrm{N} \times 1,000,000} \times 100
$$

where;

$$
\begin{aligned}
& \text { Total inorganic } \mathrm{N}=\text { sum of } \mathrm{NH}_{4}{ }^{+} \text {and } \mathrm{NO}_{3}{ }^{-} \\
& 1,000,000=\text { conversion of } \% \text { to ppm }
\end{aligned}
$$

\section{Pot Experiment}

\section{Soil and PotPreparation}

Two (2) kg of prepared (oven-dry weigh basis) soil wereplaced in each pot and arranged in an open field. Soil samples for both initial and final chemical analyses $(\mathrm{pH}$, organic Matter, total $\mathrm{N}$, available $\mathrm{P}$, and exchangeable $\mathrm{K}, \mathrm{Na}$, Ca and $\mathrm{Mg}$ ) were collected. 
A $4 \times 4$ factorial experiment was laid out in a randomized complete block design (RCBD) with three replications. Seventy-eight (78) uniform pots with a dimension of $8 \times 8 \times 13 \mathrm{~cm}$ were prepared and used as potting media containers for this experiment. Two pots per treatment per replications were prepared. There were 13 treatment combinations from four different organic amendments and four levels of each organic amendment application. These were as follows:

Factors A: Organic Amendments

$$
\begin{array}{ll}
\mathrm{O}_{1}-\text { swine manure }(2.81 \% \mathrm{~N}) & \mathrm{O}_{3}-\operatorname{mudpress}(0.69 \% \mathrm{~N}) \\
\mathrm{O}_{2}-\text { chicken dung }(4 \% \mathrm{~N}) & \mathrm{O}_{4}-\operatorname{vermicast}(1.13 \% \mathrm{~N})
\end{array}
$$

Factor B: Levels of Organic Amendments

$$
\begin{array}{cc}
\mathrm{L}_{0}-\text { no application } & \mathrm{L}_{2}-1 / 2 \text { of the reference application rate } \\
\mathrm{L}_{1}-\text { reference application rate } & \begin{array}{c}
\mathrm{L}_{3}-\text { double the reference application } \\
\text { rate }
\end{array}
\end{array}
$$

Application of Organic Amendments in combination with Inorganic Fertilizers

Incorporation of organic amendments was done a day after potting. The organic amendments were thoroughly mixed in the prepared soil according to the treatments indicated above. The amounts of each organic material was equivalent to $120 \mathrm{~kg} \mathrm{~N} / \mathrm{ha}$ applications based on the recommended rate for pechay. The computation of the added organic materials were based on previous analysis of total $\mathrm{N}$ content of each material multiplied by the amount of mineralizable N/yr (2.5\%) (Blackmer, 2000; Troeh and Thompson, 1993). In addition, amounts of solophos and muriate of potash were also applied uniformly to all pots to satisfy the $\mathrm{P}$ and $\mathrm{K}$ nutrient requirements of the plant. Pechay was used as test crop for this study. Seeds were sowed in a seedbox and allowed to germinate to ensure plant survival. After one week from germination, one germinated plant was transplanted in each pot and allowed to grow until harvesting. Planting was done one week after incorporation of organic materials.

\section{Care and Management}

Weeds were removed regularly from pot to prevent nutrients, moisture and sunlight competition. The experimental plants were watered whenever necessary. 


\section{Harvesting}

Harvesting was done after 30 days from transplanting. Harvested plants were immediately washed with tap water first then followed by distilled water. Afterwards, there were weighed. Shoots and roots were also weighed separately. This was then air-dried for three days and placed in the oven for subsequent drying. Oven dried weights were recorded. Oven dried plant tissues were analyzed (Total N, Total P, and Total K) for its nutrient content in the laboratory.

\section{Plant Parameters Gathered}

\section{a.) Growth Parameters}

1.)Plant Height - this was measured at week interval after transplanting.

2.)Average Number of Leaves/ plant - this was done by counting the number of leaves in each plant/pot at harvest.

3.)Total Fresh Weights- fresh weights of the harvested plant were recorded. Plant shoots and roots were weighed separately.

4.)Total Dry Matter (Biomass) - this was computed using the oven dry weight (ODW) of shoots and roots following the formula:

$$
\mathrm{TDM}=\mathrm{ODW} \text { of shoots }+\mathrm{ODW} \text { of roots }
$$

Shoot: Root Ratio - this was calculated using the formula;

$$
\text { Shoot: Root Ratio }=\frac{\text { ODW of shoots }}{\text { ODW of roots }}
$$

\section{b.) Yield Components}

Marketable and Non- marketable yield - After weighing, harvested plants were sorted into marketable and non- marketable plants.

\section{Laboratory Analysis}

\section{Soil Analysis}

Soil samples (before and after study) were collected and analyzed for both initial and final analysis of the following chemical parameters based 
on the protocol for comparing organic soil amendments with soluble chemical fertilizers by Eldridge and Chan (2010); Soil ph was measured potentiometrically in water using a solution ratio of 1:2.5 (ISRIC, 1995).

Total $N$ was determined using the Kjeldhal Method according to Bremner and Mulvany (1982). Available Phosphorus was extracted using $0.03 \mathrm{M} \mathrm{NH}_{4} \mathrm{~F}$ in $0.1 \mathrm{M} \mathrm{HCl}$ (Bray and Kurtz No. 2) and quantified using a spectrophotometer following the method of Murphy and Riley (1962) for color development. Exchangeable Bases (Potassium, Calcium, Magnesium, Sodium) were extracted using $1 \mathrm{~N} \mathrm{NH}_{4} \mathrm{OAc}$ adjusted to $\mathrm{pH}$ 7.0. A 2.5-gram soil sieved using a $2 \mathrm{~mm}$ mesh sieve was placed in a $50 \mathrm{ml}$ Erlenmeyer flask added with $25 \mathrm{ml}$ extracting solutions, and shaken for five minutes in a mechanical shaker. Solution was filtered using Whatman filter paper \# 42 in order to collect the needed filtrate. Quantification was done by atomic absorption spectrophotometry (AAS) (VARIAN 220 FS).

\section{Plant Tissue Analysis}

\section{Sample Collection, Preparation and Analysis}

Plant tissue samples were collected at harvest for nutrient analysis. Leaf samples were washed with distilled water, blotted dry with tissue paper, and air dried. The leaves were then oven-dried at $70^{\circ} \mathrm{C}$ for at least 3 days. The dried leaves were ground and placed in labeled paper bags ready for analysis. Total concentration of $\mathrm{P}$ and $\mathrm{K}$ in the plant samples were analyzed by dry ashing the samples at $500^{\circ} \mathrm{C}$ for a minimum of 5 hours (but not exceeding 16 hours) followed by the addition of $6 \mathrm{M}$ hydrochloric acid $(\mathrm{HCl})$. Quantification of $\mathrm{K}$ was done using an atomic absorption spectrophotometer (VARIAN 220 FS) while P was analyzed using a spectrometer (HITACHI U-2900). On the other hand, Total N was analyzed by Kjeldhal method involving sample digestion with concentrated $\mathrm{H}_{2} \mathrm{SO}_{4}$, distillation and titration.

\section{Statistical Analysis}

Statistical analysis was done using analysis of variance (ANOVA) to compare data on nutrient content, microbial decomposition and nitrogen mineralization rates of different organic amendments and plant data on growth and yield of pechay. Comparison of means was statistically analyzed using Tukey's Honestly Significant Differences (HSD) test. 


\section{RESULTS AND DISCUSSION}

\section{Total Elemental Analysis}

Total elemental analysis of the organic amendments revealed that chicken dung had the highest amounts of phosphorus, potassium, calcium, chlorine, and sodium as compared to mudpress, vermicast, and swine manure. However, high amounts of heavy metals such as strontium, lead, copper, nickel, and zinc were detected in the swine manure suggesting that the use of this organic material may cause environmental pollution of consequently crop contamination. Although copper, nickel, and zinc are considered as micronutrients, prolonged application of the material may lead to toxicity if taken by plants in large amounts which are beyond the safe limit and might cause contamination to the soil.

\section{Organic Matter Content ofOrganic Amendments used}

One of the best contributions of applying organic materials to the soil is that, it increases the soil organic matter content. Vermicast and mudpress contained high amounts of $\mathrm{OM}$ than swine manure and chicken dung (Figure 1) indicating that the former (vermicast and mudpress) are a much better source of $\mathrm{OM}$ than the latter (swine manure and chicken dung).

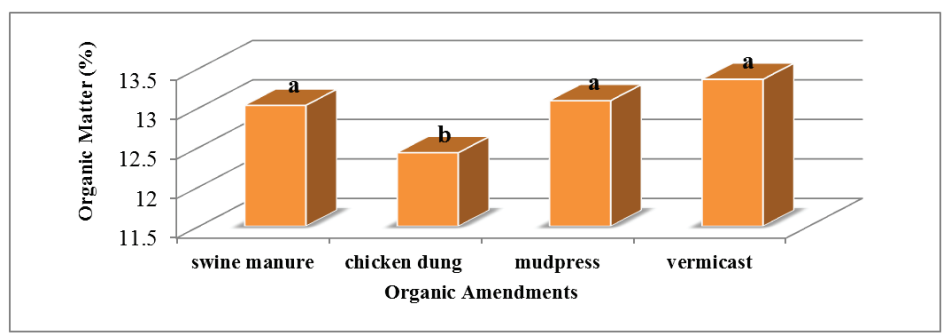

Figure 1. Organic matter content of different organic materials used in this study.

\section{Microbial Decomposition Rate}

Weekly determination of $\mathrm{CO}_{2}$ produced revealed that treatments applied with organic amendments obtained highest values compared to the control (Figure 2) indicating higher microbial activity in these treatments than in the unamended soil. Soil added with mudpress produced the highest amount of $\mathrm{CO}_{2}$ until the $4^{\text {th }}$ week incubation period as compared to other treatments due to high organic $\mathrm{C}$ content of mudpress. Organic amendments used in this study resulted in significant differences 
Various organic amendments used for pechay production

in $\mathrm{CO}_{2}$ production especially during the $1^{\text {st }}$ week of decomposition indicating faster decomposition occurred on the $1^{\text {st }}$ week. This suggests faster release of nutrients during the first week.

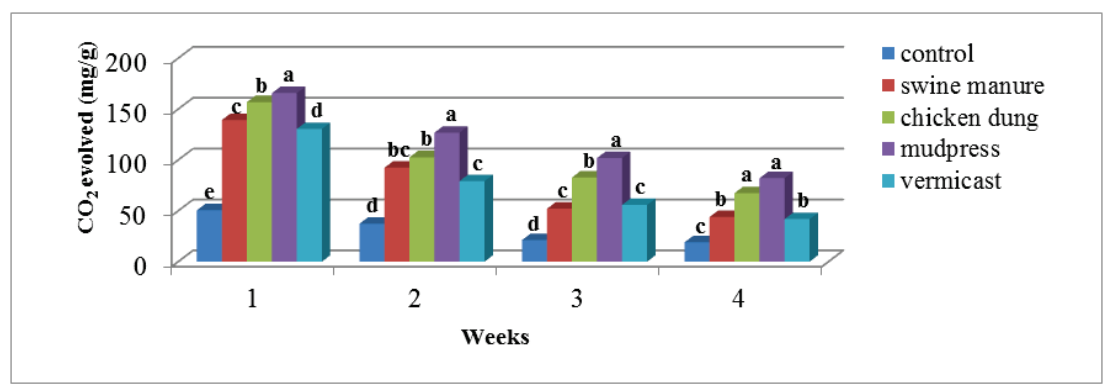

Figure 2. Measurement of $\mathrm{CO}_{2}$ evolved in organic amended soil after 4 weeks of incubation

Nitrogen Mineralization

Different organic amendments gained varied amounts of mineralized nitrogen which were significantly different on the $1^{\text {st }}$ and $3^{\text {rd }}$ weeks (Figure 3 ). Result also showed that the amount of $\mathrm{N}$ mineralized was higher in the organic amended soil compared to the unamended soil. Significant differences were obtained during the first week wherein the amount of mineralized $\mathrm{N}$ obtained in chicken dung was much higher compared to the other treatments. This implies that the nature and type of organic materials influenced the rate of mineralization as well as other chemical and biological processes.

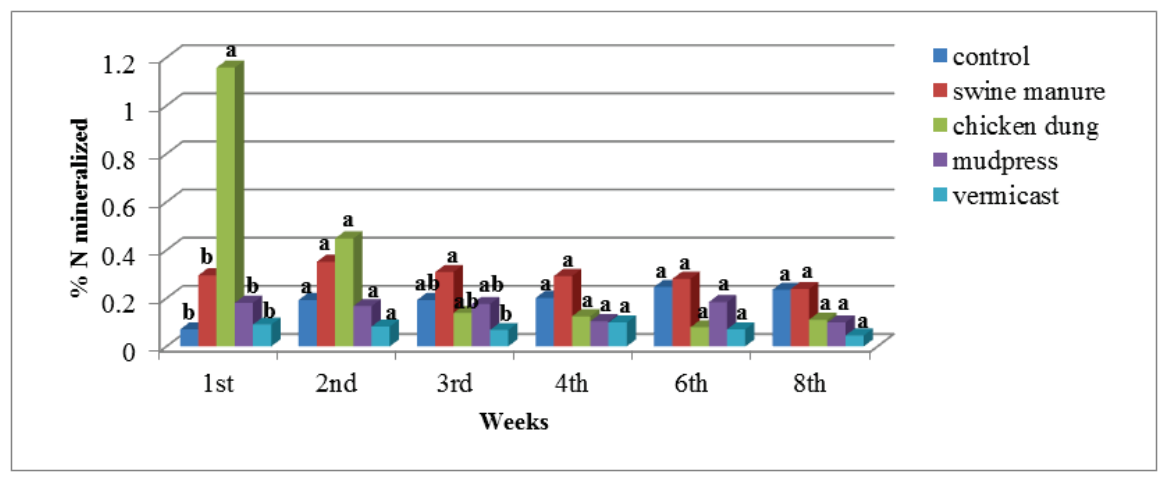

Figure 3. Percent $\mathrm{N}$ mineralized of organic amendments used after 8 weeks 


\section{Growth and Yield Components of the Plant}

Different morphological attributes (plant height, average number of leaves, fresh and oven dry weights and total dry matter), total and marketable yield were significantly higher in soil amended with organic fertilizer compared to the control (Table 1). Among the four amendments, chicken dung produced the highest values of all parameters measured. This result reveals those potential of organic amendments such as chicken dung in increasing yield of vegetable particularly pechay.

Table 1. Fresh weights, oven dry weights and average number of leaves of pechay.

\begin{tabular}{|c|c|c|c|c|c|}
\hline \multirow{2}{*}{ Treatments } & \multicolumn{2}{|c|}{ Fresh Weights } & \multicolumn{2}{|c|}{ Oven dry weights } & \multirow{2}{*}{$\begin{array}{c}\text { Ave. } \\
\text { number of } \\
\text { leaves }\end{array}$} \\
\hline & Shoots & Roots & Shoots & Roots & \\
\hline Control & $4.00^{\mathrm{b}}$ & $24.35^{c}$ & $0.50^{\mathrm{bc}}$ & $1.43^{c}$ & $9 \mathrm{~b}$ \\
\hline $1 / 2$ RR SM & $4.22^{\mathrm{b}}$ & $31.83^{c}$ & $0.38^{\mathrm{bc}}$ & $1.70^{c}$ & $8^{\mathrm{b}}$ \\
\hline $1 / 2$ RR CD & $12.8^{a}$ & $189.93 \mathrm{a}$ & $1.22^{\mathrm{ab}}$ & $6.24^{\mathrm{abc}}$ & $14^{\mathrm{ab}}$ \\
\hline $1 / 2$ RR MP & $2.82^{b}$ & $26.05^{c}$ & $0.30^{c}$ & $1.70^{c}$ & $9 \mathrm{~b}$ \\
\hline $1 / 2$ RR VC & $4.43^{b}$ & $54.3 b^{c}$ & $0.57 \mathrm{bc}$ & $3.70^{\mathrm{bc}}$ & $9^{a b}$ \\
\hline RR SM & $5.35^{b}$ & $59.82^{b c}$ & $0.60^{\mathrm{bc}}$ & $3.08^{\mathrm{bc}}$ & $11^{\mathrm{ab}}$ \\
\hline RR CD & $15.82^{\mathrm{a}}$ & $250.63^{a}$ & $1.40^{\mathrm{a}}$ & $6.37 \mathrm{a}$ & $16^{\mathrm{a}}$ \\
\hline RR MP & $3.73^{\mathrm{b}}$ & $36.77^{c}$ & $0.35^{c}$ & $2.15^{c}$ & $9^{a b}$ \\
\hline RR VC & $14.97^{a}$ & $171.85^{a}$ & $1.35^{\mathrm{a}}$ & $6.31^{\mathrm{ab}}$ & $14^{\mathrm{ab}}$ \\
\hline 2 RR SM & $4.95^{b}$ & $49.67 \mathrm{bc}$ & $0.62^{\mathrm{bc}}$ & $2.85^{\mathrm{bc}}$ & $8^{b}$ \\
\hline 2 RR CD & $12.88^{a}$ & $215.23^{a}$ & $1.09 a^{b c}$ & $3.30^{\mathrm{bc}}$ & $12^{\mathrm{ab}}$ \\
\hline 2 RR MP & $2.40^{\mathrm{b}}$ & $18.65^{c}$ & $0.25^{c}$ & $1.04^{c}$ & $9 \mathrm{~b}$ \\
\hline 2 RR VC & $12.58^{\mathrm{a}}$ & $150.23^{\mathrm{ab}}$ & $0.93^{\mathrm{bc}}$ & $3.15^{\mathrm{bc}}$ & $14^{\mathrm{ab}}$ \\
\hline CV (\%) & 28.68 & 37.32 & 38.46 & 40.23 & 20.93 \\
\hline
\end{tabular}

RR-Reference Rate; SM-Swine Manure; CD-Chicken dung; MP- Mudpress; VC-Vermicast

\section{Effects of Organic amendments on the Soil}

Final analyses of the different soil chemical parameters (\% OM, Total N, Available $\mathrm{P}$ and Exchangeable $\mathrm{K}, \mathrm{Ca}, \mathrm{Mg}$ and $\mathrm{Na}$ ) of the soil used show significant effects on soils amended with organic materials as compared to the unamended soil (Table 2). This implies that addition of organic amendment to soil contributes in increasing the nutrient supply of the soil. Mudpress and vermicast resulted in the highest OM content due to the complex component of the plant such as lignin. Mudpress amended soil has high values in terms of total $\mathrm{N}$ and available $\mathrm{P}$. The low amounts of $\mathrm{N}$ and $\mathrm{P}$ in chicken dung amended soil is attributed to the uptake of plant of these nutrients and has been therefore concentrated in the plant tissues. 
Various organic amendments used for pechay production

Table 2. Means for OM (\%), Total N (\%), exchangeable K, Ca, Mg and Na of soil as influenced by the organic amendments after harvest.

\begin{tabular}{|c|c|c|c|c|c|c|c|}
\hline \multirow{3}{*}{ Treatment } & \multicolumn{7}{|c|}{ Soil parameters } \\
\hline & \multirow{2}{*}{$\begin{array}{l}\mathrm{OM} \\
(\%)\end{array}$} & \multirow{2}{*}{$\begin{array}{c}\text { Total N } \\
(\%)\end{array}$} & \multirow{2}{*}{$\begin{array}{c}\text { Available P } \\
\text { (mg/kg) }\end{array}$} & \multicolumn{4}{|c|}{ Exchangeable Bases (mg/kg) } \\
\hline & & & & K & $\mathrm{Ca}$ & $\mathrm{Mg}$ & $\mathrm{Na}$ \\
\hline Control & $10.18^{f}$ & $0.54^{\mathrm{d}}$ & $6.16^{\mathrm{e}}$ & $0.20 \mathrm{~g}$ & $0.65^{f}$ & $0.27 \mathrm{e}$ & $0.15^{b}$ \\
\hline $1 / 2$ RR SM & $10.81^{\text {cdef }}$ & $0.59 \mathrm{~cd}$ & $9.54 \mathrm{de}$ & $0.33^{\mathrm{fg}}$ & $2.11^{\mathrm{ef}}$ & $0.53^{\mathrm{de}}$ & $0.14^{\mathrm{b}}$ \\
\hline $1 / 2$ RR CD & $10.52^{\mathrm{ef}}$ & $0.59 \mathrm{~cd}$ & $17.07^{\mathrm{de}}$ & $1.65^{c}$ & $4.80^{\text {cdef }}$ & $2.12^{\text {cde }}$ & $0.34^{b}$ \\
\hline $1 / 2$ RR MP & $11.35^{\text {bcde }}$ & $0.63^{\mathrm{bcd}}$ & $39.10^{\mathrm{ab}}$ & $0.61^{\mathrm{g}}$ & $8.36^{\text {bcde }}$ & $2.14^{\text {cde }}$ & $0.15^{b}$ \\
\hline $1 / 2 \mathrm{RR}$ VC & $10.95^{\text {cdef }}$ & $0.60^{\mathrm{bcd}}$ & $13.84^{\text {de }}$ & $1.55^{\mathrm{cd}}$ & $5.64^{\text {cdef }}$ & $4.19 \mathrm{~cd}$ & $0.26^{b}$ \\
\hline RR SM & $11.27 \mathrm{bcde}$ & $0.61^{\mathrm{bcd}}$ & $13.42^{\mathrm{de}}$ & $0.46^{\mathrm{fg}}$ & $3.06^{\text {def }}$ & $0.68^{\mathrm{de}}$ & $0.17 \mathrm{~b}$ \\
\hline RR CD & $10.74^{\mathrm{def}}$ & $0.62^{\mathrm{bcd}}$ & $20.36^{\text {de }}$ & $2.55^{\mathrm{d}}$ & $6.63^{\text {bcdef }}$ & $3.44^{\text {cde }}$ & $0.46^{b}$ \\
\hline RR MP & $11.77^{a b c}$ & $0.75^{\mathrm{a}}$ & $49.04^{\mathrm{ab}}$ & 0.94 def & $13.45^{\mathrm{ab}}$ & $3.73^{\text {cde }}$ & $0.18^{b}$ \\
\hline RR VC & $11.11^{\text {bcdef }}$ & $0.62^{\mathrm{bcd}}$ & $19.20^{\text {de }}$ & $2.59^{\mathrm{b}}$ & $9.84^{\mathrm{abcd}}$ & $8.55^{\mathrm{ab}}$ & $0.25^{b}$ \\
\hline 2 RR SM & $11.65^{\mathrm{abcd}}$ & $0.65^{b c}$ & $22.00^{\mathrm{cd}}$ & $0.69^{\text {efg }}$ & $7.18^{\text {bcdef }}$ & $3.35^{\text {cde }}$ & $0.17^{b}$ \\
\hline 2 RR CD & $10.68^{\mathrm{def}}$ & $0.69^{\mathrm{ab}}$ & $35.89^{b c}$ & $3.13^{\mathrm{ab}}$ & $13.19^{\mathrm{ab}}$ & $3.07^{\text {cde }}$ & $0.92^{\mathrm{a}}$ \\
\hline 2 RR MP & $12.40^{\mathrm{a}}$ & $0.76^{a}$ & $53.15^{\mathrm{a}}$ & $1.33^{\text {cde }}$ & $15.33^{\mathrm{a}}$ & $4.98^{\mathrm{bc}}$ & $0.19^{b}$ \\
\hline 2 RR VC & $12.07 \mathrm{ab}$ & $0.74^{a}$ & $53.50^{a}$ & $3.33^{\mathrm{a}}$ & $10.17^{a b c}$ & $10.97^{a}$ & $0.33^{b}$ \\
\hline CV (\%) & 2.99 & 4.87 & 25.95 & 15.88 & 29.97 & 34.48 & 51.75 \\
\hline
\end{tabular}

RR- Reference Rate; SM- Swine Manure; CD- Chicken Dung; MP- Mudpress; VC- Vermicast

\section{CONCLUSION}

In terms of total elemental analysis, chicken dung had the highest content of $\mathrm{P}, \mathrm{K}, \mathrm{Ca}, \mathrm{Cl}, \mathrm{Mo}$, and $\mathrm{Na}$ as compared to mudpress, vermicast, and swine manure. Swine manure contained high amounts of $\mathrm{Pb}, \mathrm{Sr}, \mathrm{Ni}, \mathrm{Cu}$, and Zn.Organic amended soils have higher microbial decomposition rate as compared with the unamended one. Highest microbial decomposition was noted at $1^{\text {st }}$ week of incubation.

Nitrogen mineralization rate was higher in organic amended soils than without amendment and the rate declined starting from the $2{ }^{\text {nd }}$ week until the last week of the incubation period. Chicken dung obtained the highest amount of mineralized $\mathrm{N}$ on the $1^{\text {st }}$ week followed by swine manure, mudpress and vermicast in descending order.

Chicken dung significantly increased most of the growth and yield parameters of pechay, thus has good potential as source of organic fertilizer for vegetable production especially in enhancing the $\mathrm{N}$ and $\mathrm{P}$ 
levels of plant tissue. It also produced the highest marketable yield of pechay.

\section{ACKNOWLEDGMENT}

The paper is based on the MS Soil Science thesis of the first author (CAEV). She is thankful to the Department of Science and Technology (DOST) for the ASTHRDP Graduate Scholarship which made her graduate work at VSU possible. Additional financial support for the thesis research was provided by the ACIAR-funded project (Hort/2007/006/1) entitled "Integrated soil and crop nutrient management of vegetable crops in the Southern Philippines" (Dr. C. Dorahy).

\section{REFERENCES}

ANDERSON, J.P.E. 1982. Soil Respiration. p.83-871. In A.L. Page et al. (ed). Methods of soil analysis, Part 2. Chemical and microbiological properties. Agronomy Monograph No. 9. ASA and SSSA, Madison, WI.

BLACKMER, A.M. 2000. Bioavailability of Nitrogen: In: Handbook of Soil Science (M.E. Sumner, ed). CRC Press, Boca Raton.

BREMNER, J.M. and C.S. MULVANEY. 1982. Nitrogen - Total. In: Methods of Soil Analysis (Page et. al., eds) Part 2. Chemical and Microbiological Properties. $2^{\text {nd }}$ edition. Soil Sci. Soc. Amer. \& Amer. Soc. Agron., Madison Wisconsin.

DORAHY C., A. MERCADO JR., C.M. QUIÑONES, R. BIGAMON, J. SALVANI, C. LAPOOT, V. JUSTO, J. OAKSHOTTE, J. ATIENZA, A. TULIN. 2010. A framework for prioritizing nutrient management research for vegetable production in the Southern Philippines. In Gilkes, RG, Prakongkep N, editors. Proceedings of the $19^{\text {th }}$ World Congress of Soil Science; Soil Solutions for a Changing World; ISBN 978-0-646-537832; Published on DVD; http://www.iuss.org; Symposium 3.3.1; Integrated nutrient management; 2010 Aug 1-6. Brisbane, Australia: IUSS; 2010, pp. 5-8.

ELDRIDGE, S. and Y. CHAN. 2010. Protocol for comparing organic soil amendments with soluble chemical fertilizers. Industry and Investment, NSW, Richmond. 
Various organic amendments used for pechay production

ISRIC. 1995. Procedure for Soil Analysis (L.P. Van Reuwijk, Editor). Wageningen, Netherlands.

MITCHELL, J., M. GASKELL, R. SMITH, C. FOUCHE and S. KOIKE. 2000. Soil Management and Soil Quality for Organic Crops. Reagents of University of California, Division of Agriculture and Natural Resources. Oakland, CA.

MURPHY, J. and J.C. RILEY. 1962. A modified single solution for determination of phosphorus in natural waters. Anal. Chem. Act. 27:31-36.

SCHLICHTING, E., H.P. BLUME and K. STAHR. 1995. Soil Science Practicum. $2^{\text {nd }}$ ed. Blackwell Wissenschafts Verlag, Berlin.

STANFORD, G. and S. J. SMITH. 1972. Nitrogen Mineralization Potential of Soils. Soil Sci. Soc. Am. Proc. 36:465-472.

TROEH, F.R. and L.M. THOMPSON. 1993. Soils and Soil Fertility. $5^{\text {th }}$ edition. Oxford University Press, Inc. New York.

TULIN , A.B., C.M. QUIÑONES, R. RALLOS , A. MERCADO JR., J. SALVANI, C. LAPOOT, V. JUSTO, C. DORAHY. 2010. Evidence-based nutrient management strategy in identifying fertility status and soil constraints for vegetable production in Southern Philippines. In Gilkes, RG, Prakongkep N, editors. Proceedings of the $19^{\text {th }}$ World Congress of Soil Science; Soil Solutions for a Changing World; ISBN 978-0-646-537832; Published on DVD; http://www.iuss.org;_Symposium 3.3.1; Integrated nutrient management; 2010 Aug 1-6. Brisbane, Australia: IUSS; 2010, pp. 168-171. 